\title{
THE COMPATIBILITY OF ISLAM WITH PLURALISM: TWO HISTORICAL PRECEDENTS
}

\author{
Maher Y. Abu-Munshar
}

\begin{abstract}
For Muslims, Islam is a religion of peace and harmony. For many non-Muslims today, it appears as a religion that promotes hatred and violence. Sadly, terrorist attacks, often carried out by Muslims, have exacerbated prejudices against Islam and Muslims in general, leading many non-Muslims to believe that Muslims are inherently militant and irrational people who neither tolerate nor accept living and cooperating with the followers of other religions and that Islam does not believe in pluralism and diversity. In this article, two important historical precedents will be elaborated and critically analysed. The first is the 'Constitution of Medina' (Şahịfat al-Madinah), while the other is 'Umar b. al-Khațțāb's 'Assurance of Safety' to the people of Aelia - Byzantine Jerusalem - which he granted to them upon his conquest of the city in 637, guaranteeing their security and religious freedom. By studying these two historical precedents, the author attempts to demonstrate that Islam - as outlined in the Qur'ān and exemplified by the life of Muhammad and his Companions - actually accepts, celebrates and even encourages diversity and pluralism. Although documents and historical events can certainly also be interpreted differently, the author's views are somewhat representative for the standard Muslim perspective on intercultural relations.
\end{abstract}

\section{Introduction}

Despite the substantial number of scholarly works and news stories to the contrary, many people still have the unfortunate misconception that Muslims cannot tolerate, coexist, or cooperate with followers of other religions and hence Islam does not support diversity and pluralism. This is partly because Muslim extremists themselves often (mis)use qur'ānic verses and Islamic theology to justify acts of violence against non-Muslims. By contrast, history reveals that the teachings of the Qur'ān, the Prophet Muhammad and his Companions actually do accept, celebrate and even encourage diversity and pluralism.

* Dr Maher Y. Abu-Munshar is Visiting Senior Lecturer in the Department of Islamic History and Civilisation at the Academy of Islamic Studies, University of Malaya, Kuala Lumpur. 
This article presents a critical analysis of two important historical incidents and documents. The first is the so-called 'Constitution of Medina' (Şahîfat al-Madinah), while the other is 'Umar b. al-Khaț̣āb's 'Assurance of Safety', an Assurance to the inhabitants of Aelia ${ }^{1}$ - Byzantine Jerusalem - which was granted by the caliph 'Umar b. al- Khatțāb upon his arrival to the region in 637CE. I chose these two incidents because firstly, both incidents involved Muslims who were in control and had power over their non-Muslim citizens. Secondly, they are among the most important examples of plural societies in Muslim history, in which both the Prophet Muhammad and 'Umar succeeded in establishing diverse and multicultural societies. Hence their understanding of the rights of non-Muslims. The recognition of the needs of the two communities in Medina and Jerusalem engendered a flourishing of plural societies that provided an atmosphere for peaceful coexistence.

\section{The Prophet Muḥammad's Implementation of Pluralism}

In 622, when the Prophet migrated from Mecca to Medina and started to build the first Muslim state, he ensured that Medina's Muslim and non-Muslim inhabitants could coexist in harmony. There was a substantial Jewish community in Medina, and the Prophet proposed an agreement of cooperation between the Muslims and the eleven Jewish tribes, today often referred to as the 'Constitution of Medina', which Muslim historians and scholars generally accept as the first written state constitution. This 'Constitution' spelled out the rights of the Jews as non-Muslim citizens in the Muslim state. As a result, the Prophet managed to establish a multi-religious political community in Medina based on a set of universal principles. The rules set out in the 'Constitution' were meant to maintain peace and cooperation, protect life and property, prevent injustice and ensure freedom of religion and movement for all inhabitants regardless of tribal or religious affiliation. The Prophet's treatment of the 'People of the Book' - in this case Jews - showed religious tolerance as well as prudence. The 'Constitution' established the pattern for the future relationship between Muslims and non-Muslims, specifying non-Muslim citizens as equal partners with Muslim inhabitants.

It can be argued that developing a constitution to regulate the internal and external affairs of the city was one of the major contributions of the Prophet and his Companions in Medina, which can be considered a turning point for its inhabitants. This remarkable work was developed and administrated by the Prophet himself. The task, with its many civil, judicial and political articles, including defence and alliance, had to be coordinated and approved by the leaders of the eleven Jewish tribes, by the leaders of the Arab tribes in and around the city and by the Muslims themselves. The 'Constitution' was based on cooperation, maintaining virtue and 
preventing evil. Regarded as the first-ever written constitution by Muslims, the document stated reciprocal obligations as follows:

In the name of God the Compassionate, the Merciful

This is a document from Muhammad the Prophet [governing the relations] between the believers and the Muslims of Quraysh and Yathrib and those who are to follow and join them [...]. The Jews shall contribute to the cost of war so long as they are fighting alongside the believers. The Jews of the Banū 'Awf are one community with the believers (the Jews have their religion and the Muslims have theirs), their freemen and their persons except those who behave unjustly and sinfully, for they hurt only themselves and their families. The same applies to the Jews of the Banū 'l-Najjār, Banū 'l-Hārith, Banū Sa 'T̃dah, Banū Jusham, Banū Aws, Banū Tha 'labah, and the Jafnah, a clan of the Tha 'labah and the Banū 'l-Shutaybah. Loyalty is a protection against treachery. The freemen of Tha 'labah are as themselves. The close friends of the Jews are as themselves. None of them shall go out to war save with the permission of Muhammad, but anyone shall not be prevented from taking revenge for a wound. He who slays a man without warning slays himself and his household, unless it be one who has wronged him, for God will not accept that. The Jews must bear their expenses and the Muslims their expenses. Each must help the other against anyone who attacks the people of this document. They must seek mutual advice and consultation, and loyalty is a protection against treachery. A man is not liable for his ally's misdeeds. The wronged must be helped. The Jews must pay with the believers so long as war lasts. Yathrib shall be a sanctuary for the people of this document. A stranger under protection shall be as his host doing no harm and committing no crime. A woman shall only be given protection with the consent of her family. If any dispute or controversy likely to cause trouble should arise it must be referred to God and to Muhammad the apostle of God. God accepts what is nearest to piety and goodness in this document. The Quraysh and their helpers shall not be given protection. The contracting parties are bound to help one another against any attack on Yathrib. If they are called to make peace and maintain it they must do so; and if they make a similar demand on the Muslims it must be carried out except in the case of a holy war. Every one shall have his portion from the side to which he belongs. The Jews of al-Aws, their freemen and themselves have the same standing with the people of this document in pure loyalty from the people of this document. Loyalty is a protection against treachery: He who acquires aught acquires it for himself. God approves of this document. This deed will not protect the unjust and the sinner. The man who goes forth to fight and the man who stays at home in the city is safe unless he has been unjust and sinned. God is the protector of the good and God-fearing man and Muhammad is the apostle of God. ${ }^{2}$

As stated earlier, the rules enunciated in the 'Constitution' were aimed at maintaining peace and cooperation, protecting the life and property of the inhabitants 
of Medina, fighting aggression and injustice regardless of tribal or religious affiliation, and ensuring freedom of religion and movement. It supported community defence against enemies and promoted justice, and resistance to evil. Jews and Muslims lived side by side in peace for many years. In discussing this document, alMubarakpuri noted that it came within the context of a larger framework of Muslim relationships. He summarised the most important provisions of the document in twelve points: ${ }^{3}$

1. The Jews of Banū 'Awf are one community with the believers. The Jews will profess their religion and the Muslim theirs.

2. The Jews shall be responsible for their expenditure, and the Muslims for theirs.

3. If attacked by a third party, each shall come to the assistance of the other.

4. Each party shall hold counsel with the other. Mutual relations shall be founded on righteousness; sin is totally excluded.

5. Neither shall commit sins to the prejudice of the other.

6. The wronged party shall be assisted.

7. The Jews shall contribute to the cost of war so long as they are fighting alongside the believers.

8. Medina shall remain sacred and inviolable for all that join this treaty.

9. Should any disagreement arise between the signatories to this treaty, then God, the Most High, and His Messenger shall settle the dispute.

10. The signatories to this treaty shall boycott the Quraysh commercially; they shall also abstain from extending any support to them.

11. Each shall contribute to defending Medina, in case of a foreign attack, in its respective area.

12. This treaty shall not hinder either party from seeking lawful revenge.

Al-Būṭ̂ - a leading contemporary Syrian Muslim jurist - attempted to explain the significance of this constitution by referring to a major clause: "The Jews of the Banū 'Awf are one community with the believers (the Jews have their religion and the Muslims have theirs), their freemen and themselves except those who behave unjustly and sinfully, for they hurt but themselves." He comments that this is a clear and straightforward text showing that the Muslim state - Medina - is a partnership between two different groups, Muslims and Jews. ${ }^{4}$ No one would be excluded from this partnership except those who behaved unjustly. The appeal of this is that "except those" does not apply only to Jews, but to everyone resident in Medina. He argues that when the constitution of Medina states: "The Jews of the Banū 'Awf are one community with the believers", it did not mean that they were part of the Muslim community. If this was the case, it would be a clear statement that their identity was merged into the Muslim state. However, the constitution 
gave them the right to be an independent community inside the Muslim state. Furthermore, al-Būṭi adds that other clauses in this constitution assign equality of duties and rights to all the inhabitants of the Muslim state, and none of the clauses is derived from religious differences. ${ }^{5}$

Hamidullah goes further, saying that with this constitution the autonomous Jewish villages acceded of their free will to the confederate state, and as a result recognised Prophet Muhammad as their supreme political head. He says this implies that non-Muslim citizens possessed voting rights in electing the head of the Muslim state. $^{6}$

It is remarkable that the Medina constitution placed rules of justice over and above religious solidarity, and affirmed the right to justice of the victims of aggression irrespective of tribal or religious affiliation. Of course, any newly established state must work hard to integrate all inhabitants regardless of religion, race or colour, in order to ensure the state's continuation and stability. El-Awaisi argues that core Muslim teachings reject the philosophy of a conflict based on eliminating the other party so that the victor could have the stage to himself. ${ }^{7}$ He adds that:

As confirmation of that idea, Islam favoured another method, namely tadāfu' or counteraction, as a means of adjusting positions using movement instead of conflict [...]. This conflict-free method is what Islamic teachings see as a means of preserving a non-Muslim presence in this life. Tadāfu' is not only to preserve Muslim's sacred places, but to preserve the sacred places of others. The Qur'an says: 'And if God had not counteracted ( $d u f^{\prime} u$ ) to some people's deeds by others, there surely would have been pulled down monasteries, churches, synagogues, and mosques, wherein the name of God is commemorated in abundant measure. ${ }^{8}$ This means that, from a Muslim point of view, tadāfu' is the means of preserving a plurality of sacred places or the plurality of religions. ${ }^{9}$

Moreover, one of the aims of Islam is to provide a peaceful life based on mutual respect. At the time there were no Christians in Medina, but the Prophet would have established with them an agreement similar to the Medina constitution, with the same conditions, had they been living in the city. The Prophet's blueprint for a plural society carries the same moral authority as any other of his practices. The principles of Islam were intended to apply in all places where Muslims lived alongside the followers of other religions.

To sum up, the Prophet's attitude towards the 'People of the Book' - in this case Jews - showed religious tolerance as well as prudence. The constitution established the pattern for future relations in the Muslim state between Muslims and non-Muslims. The basic principle was religious tolerance and non-interference in the religious affairs of the non-Muslim group. The constitution recognised freedom of religion for all citizens. It made non-Muslim citizens equal partners with the Muslim inhabitants of Medina in the material wealth and progress of the Muslim 
state. It gave rights of protection, security, peace and justice not only to Muslims, but also to Jews who lived in Medina, as well as to allies of the Jews who were non-Muslims. It allowed Jews to practise their religion freely.

\section{'Umar's Implementation of Pluralism in Jerusalem}

When Muslims conquered Aelia (Byzantine Jerusalem) in the year 637, caliph 'Umar b. al-Khatțāb gave an 'Assurance' to its inhabitants - who were mainly Christians - that guaranteed their security and religious freedom. This document, known in Arabic as al- 'Uhdah al- 'Umariyyah, is of great importance since it defines the status of Christian communities under the new Muslim rule and establishes the foundation for a plural society and legislates how Muslims should treat Christians in Muslim-ruled territories (Jerusalem in this case). Nevertheless, opinions differ concerning its authenticity. It is therefore important to describe the various versions of the Assurance and to examine one of them more closely. This is al-Tabarī's version, recorded almost three centuries after the event but regarded as the most famous and longest version of the 'Assurance'.

It is obvious from searching the literature that not all historians have reported the text of 'Umar's 'Assurance'. The early historians, such as al-Wāqidī (d. 822), al-Balādhurī (d. 892), Ibn al-Athīr (d. 1233), and Abū 'l-Fidā' (d. 1332), confined themselves to discussing the significance of the 'Assurance' rather than the text itself. Other historians, such as al-Ya 'qūbī (d. 897), the patriarch of Alexandria, Eutychius (Ibn al-Bațrīq) (d. 940), al-Ṭabarī (d. 922), al-Ḥimyarī (d. 1327), Mujīr al-Dīn al-Hanbalī (d. 1521) and Ibn al-Jawzī (d. 1200), reported the text of this document in their books, either in an abridged version or as a long text.

Al-Wāqidī is among the earliest historians to report (twice) the content of 'Umar's Assurance, without the text, in his book Futūh al-Shām (The Conquests of Syria). In the first narration he says that when 'Umar came to Jerusalem and was identified by its inhabitants, they opened the gates of the walled city and went out to ask for the pact and for a dhimmi ${ }^{10}$ contract. They accepted that they would have to pay the jizyah. ${ }^{11}$ 'Umar agreed, and told them to go back to their homes. Having been granted what they asked for, they returned to their homes and left the gates of the city wide open. ${ }^{12}$ In his second narration, al-Wāqidī reports that 'Umar went to Aelia and stayed there ten days after he had written the Assurance for its Christian inhabitants, and that he allowed them to stay in Aelia in return for paying jizyah. ${ }^{13}$

Al-Balādhurī mentions three narrations about the conquest of Jerusalem and the significance of 'Umar's 'Assurance'. According to the first one, when Abū 'Ubaydah - commander-in-chief of the Muslim army - was besieging the city of Aelia, the Christians besought him to grant peace and safety to them like that given the Christians of the cities of al-Sham,${ }^{14}$ on terms of payment of jizyah and kharāj 
(land tax). They were willing to conclude a peace treaty on one condition, that 'Umar would come from Medina in person to conclude it. Abū 'Ubaydah wrote to 'Umar, with the result that 'Umar came to al-Jäbiyah, then travelled to Jerusalem where he wrote the 'Assurance'. ${ }^{15}$

In the second narration transmitted by al-Balādhurī, in the name of Yazīd b. Abī Ḥabīb, 'Umar dispatched Khālid b. al-Thābit al-Fahmī with troops from al-Jābiyah ${ }^{16}$ to Jerusalem. After a brief battle the city was handed over to Khālid, who concluded a peace treaty according to which the area inside the city walls was to remain in possession of the Christians, while the area outside it became the property of the Muslims. The treaty was agreed on condition that 'Umar would ratify it in person. Khâlid informed 'Umar of the inhabitants' readiness to surrender, whereupon the latter travelled from al-Jābiyah to Jerusalem and took possession of the city on these conditions. 'Umar then returned to Medina. ${ }^{17}$

In the third narration, al-Balādhurī reported that $\mathrm{Abu}$ ' 'Ubaydah went to Palestine after the conquest of Qinnsarīn in Syria in the year 637 and led the siege on Jerusalem, whose inhabitants asked him for a peace treaty. He accepted their request in 638, on condition that 'Umar himself would come to ratify it and would write to them accordingly. ${ }^{18}$

Ibn al-Athīr wrote a note about the significance of the 'Assurance' to the people of Jerusalem. He reported that the Christians of Jerusalem sent a delegation to 'Umar while he was staying at al-Jābiyah. When the Muslims saw a detachment of horsemen with drawn swords glittering in the sun coming towards their camp, they took up arms in order to beat back what appeared to be an enemy attack (of Christians). However, 'Umar realised at once that it was a delegation from Jerusalem coming to offer surrender. The caliph then wrote an Assurance of Safety for the Christians of Jerusalem in return for their payment of jizyah, and they opened the gates of the walled city to him. ${ }^{19}$

These narrations agree that the Christians of Jerusalem were granted an Assurance in return for the payment of jizyah. On the other hand, al-Ya 'qūbi was among the first historians to give an abbreviated narration of this document, as follows:

You are given safety of your persons, properties and churches that will not be inhabited (taken over) or destroyed unless you cause some public harm. ${ }^{20}$

Eutychius gave a similar text:

This is a document from 'Umar b. al-Khaț̣āb to the people of Aelia [Jerusalem]. They are given safety of persons, children [sons and daughters], and churches that will not be destroyed or inhabited [by Muslims]. ${ }^{21}$

These two versions differ little and appear to have been taken from the same source. Mujīir al-Dīn al-Ḥanbalī provided a text similar to al-Ṭabarî̀s version (see below) 
and quoted from Sayf b. Ab̄̄ Hazm, via 'Uthmān, via Khālid and 'Ubādah. There is no difference between al-Tabarī's and al-Hanbalī's versions, except in some vocabulary which does not necessarily change the meaning. Ibn al-Jawzī (d. 1200) gave nearly the same text, which was reported by Sayf via al-Ṭabarī. The only difference is that Ibn al-Jawzī's version comes as a summary to al-Ṭabarī's. ${ }^{22}$ It runs as follows:

'Umar wrote to the inhabitants of Bayt al-Maqdis [Jerusalem]: I guarantee for you the safety of your persons, properties, families, your crosses and your churches. You will not be taxed beyond your means and whosoever decides to follow his people then he will be guaranteed safety (amān) and you pay the kharāj like the other cities of Palestine. ${ }^{23}$

It should be added that Ibn al-Jawzī, when naming the witness to 'Umar's 'Assurance', substituted 'Alī b. Abī Ṭālib for 'Amr b. al- 'Āṣ, who was named in al-Ṭabarī's version. Nevertheless, history shows that 'Alī b. Abī Țālib was in Medina at that time. ${ }^{24}$

\section{Al-Ṭabarī's Version of 'Umar's 'Assurance'}

Al-Ṭabarī was born in 839 and wrote his history between 902 and $915 .{ }^{25}$ His version of 'Umar's 'Assurance' is quoted from Sayf b. 'Umar (d. 786):

In the name of God, the most Merciful, the most Compassionate. This is the assurance of safety (amān) which the worshipper of God [the second caliph] 'Umar [b. al-Khațțāb], the Commander of the Faithful, has granted to the people of Aelia [Jerusalem]. He has granted them an assurance of safety (amān) for their lives and possessions, their churches and crosses; the sick and the healthy [to everyone without exception]; and for the rest of its religious communities. Their churches will not be inhabited [taken over] nor destroyed [by Muslims]. Neither they, nor the land on which they stand, nor their cross, nor their possessions will be encroached upon or partly seized. The people will not be compelled (yukrahuna) in religion, nor any one of them be maltreated (yadarruna). No Jews should reside with them in Aelia. The people of Aelia must pay the jizyah tax like ahl al-Madāin, the people of the [other] region/cities, they must expel the Byzantines and the robbers. As for those [the first Byzantine group] who will leave [Jerusalem], their lives and possessions shall be safeguarded until they reach their place of safety, and as for those [the second Byzantine group] who [choose to] remain, they will be safe. They will have to pay tax like the people of Jerusalem. Those people of Jerusalem who would like to leave with the Byzantines, take their possessions, and abandon their churches and crosses will be safe until they reach their place of safety.

Whosoever was in Jerusalem from the people of the land (ahl al-ard) [e.g., refugees from the villages who sought refuge in Aelia] before the murder of fulan [name of a person] 
may remain in Aelia if they wish, but they must pay tax like the people of Aelia. Those who wish may go with the Byzantines, and those who wish may return to their families. Nothing will be taken from them until their harvest has been reaped. The contents of this assurance of safety are under the covenant of God, are the responsibilities of His Prophet, of the Caliphs, and of the Faithful if [the people of Jerusalem] pay the tax according to their obligations. The persons who attest to it are: Khālid b. al-Walīd, 'Amr b. al-'Āṣ, 'Abd al-Raḥmān b. 'Awf, and Mu'āwiyah b. Abī Sufyān. This assurance of safety was written and prepared in the year $15[\mathrm{AH}]{ }^{26}$

Al-Ṭabarī was among the few Muslim historians who supported their narrations by naming the chain of narrators (isnād). In spite of this, 'Ajīn, on examining al-Ṭabarı̄'s version, commented that its chain of narrators was broken and its content could not be attributed to 'Umar. He therefore refuted the authenticity of al-Tabarī's version, claiming it was produced and had become popular in circumstances when Muslims were weak, and was intended to show non-Muslims that Islam was tolerant of other religions. ${ }^{27}$ At the same time he asserted that the 'Pact of 'Umar' ${ }^{28}$ should be the basis of the way in which Muslims should treat Christians.

El-Awaisi, on the contrary, argues that Sayf b. 'Umar's chain of narrators quoted in al-Ṭabarī is strong and valid. He bases his argument on the fact that two narrators, Khālid b. Mi dān al-Shāmī (d. 726) ${ }^{29}$ and 'Ubādah b. Nasā'ī (d. 736), ${ }^{30}$ were trustworthy 'Followers' ( $t \bar{a} b i$ ' $\bar{u} n$ ) of the first generation after the companions of the Prophet. ${ }^{31}$

I agree with El-Awaisi on the strength of the chain of narrators in al-Tabarī's version, for three reasons. First, the opening paragraph of this Assurance is in line with the treaties issued to other cities in the Bilād al-Shàm region. Second, the versions narrated by historians before al-T Tabarī did not differ much from the essence of his version; and third, 'Umar's conduct towards the Christians of Jerusalem after the conquest, described below, reflects a clear implementation of the conditions stated in al-Tabarî's version. Nevertheless, it is necessary to discuss the text in order to determine the extent to which this document can be accepted as a blueprint for the way Muslims should treat Christians in Jerusalem.

\section{The Document's Core Statements}

The statement that 'Umar granted the people of Aelia - Jerusalem - safety for "their persons, their possessions and churches" represented the normal terms of the assurances granted by Muslims to all conquered peoples at that time. With the exception of the condition relating to the Jews, the first paragraph of al-Țabarī's version is similar to these treaties. Such guarantees reflected the spirit of tolerance shown by the conquering Muslims ${ }^{32}$ towards non-Muslim peoples. It is clearly 
stated that the lives, properties and religion of Christian subjects would be safe from any kind of interference or molestation, their churches would not be damaged or demolished and no encroachment would be made on areas near churches. Freedom of religion was assured in the stipulation of no compulsion in respect of religion. Because these commitments conformed to the regular practice of a Muslim conqueror, the essentials of the document can be treated as authentic.

El-Awaisi argues that 'Umar did not sign a treaty between the two parties, but gave the people of Aelia an assurance of safety. ${ }^{33}$ I agree with this and would like to emphasise the importance of distinguishing between giving an assurance and asking for one. In normal circumstances, a peace treaty emerges as a result of negotiations between two parties. In this case, only one party - the Muslims - signed 'Umar's 'Assurance'. The Christians - led by St Sophronius (560-638), Patriarch of Jerusalem from 634 until his death - do not seem to have signed this document. This indicates that the Assurance was given to them as a pledge rather than as a treaty.

\section{Exclusion of the Jews}

The weaknesses in al-Tabarī's version start with the statement that the Jews should be banned from living with the Christians in Jerusalem. This restriction was not supported, or even mentioned, in any narrations before al-Țabarī's. It does not seem to be have been implemented, especially as there is no mention in the Muslim record that 'Umar expelled Jews from Jerusalem or prevented them from staying there. Al-Qudāh argues that it is strange to have a condition in the Assurance that was not implemented. He comments that it was well-known that Muslims in general respected pacts and followed them accordingly. ${ }^{34}$

Al-Duri refutes the condition of excluding Jews from living in Jerusalem in this version of 'Umar's 'Assurance'. He asserts that details prohibiting a certain population from living in a conquered city were unusual and never appear in the texts of similar pacts made in al-Shäm. The reference to Jews in the 'Assurance' is apparently absent from all Muslim literature. Al-Duri adds that it is believed this information first appeared in the chronicle of Michael the Syrian (d. 1199). ${ }^{35}$ Another historian, al-Himyarī, attributes it to a specific demand made by the Christians of Jerusalem. ${ }^{36}$ Ibn al-Jawzī does not even refer to the Jews when discussing 'Umar's 'Assurance' in his book, Fad̄a 'il al-Quds (The Merits of Jerusalem). ${ }^{37}$

El-Awaisi argues that the exclusion of Jews from residing in Aelia (during the first Muslim conquest) is not confirmed historically. He says that this condition is unacceptable under Muslim law, as it contradicts the basic teaching of Islam, ${ }^{38}$ and supports his argument by citing verses 60:8-9 from the Qur'ān. ${ }^{39}$ Moreover, Karen Armstrong states that: 
When Caliph 'Umar conquered Jerusalem from the Byzantines, he was faithful to the Islamic inclusive vision. Unlike Jews and Christians, Muslims did not attempt to exclude others from Jerusalem's holiness. Muslims were being taught to venerate them. ${ }^{40}$

It was not the policy of Muslims to prevent dhimmīs from living in the Muslim state, as all had equal rights of residency in Jerusalem. This leads me to argue that the reason behind this condition was the conflict between Christians and Jews.

\section{The Conflict between Christians and Jews}

The recurrent conflict between Christians and Jews in Jerusalem began when the region was under Roman rule in the first century CE and continued after the Jewish revolts against the Roman Empire in $66 \mathrm{CE}$, and especially $132 \mathrm{CE}$, ${ }^{41}$ when the Romans expelled the Jews from the region of Jerusalem and forbade them to enter the city. ${ }^{42}$ This was almost 500 years before the Muslim conquest. The situation did not improve when Christianity became the state religion of the Roman Empire under Theodosius I (r. 379-95) in 391. On the contrary, the regime followed the policy of its predecessors and continued the expulsion of Jews from Jerusalem. Nevertheless, there were short periods when Jews were allowed to stay in Jerusalem, such as during the Persian occupation of 614-28. ${ }^{43}$

This conflict was apparent during the Muslim conquest of Bilād al-Shām. The Jews were very keen to go back to Jerusalem, and hoped that the Muslims would conquer Jerusalem and allow them to do so. ${ }^{44}$ Sarkīs (d. 1915) provides examples of the "cruel aggression and oppressions of the Byzantines", to which the Jews had been subjected for a long time. For instance, he states that the Emperor Constantine I (d. 337) oppressed the Jews and forced them to convert to Christianity. Some Jews did convert, others pretended to be Christians and those who refused were killed. ${ }^{45}$ In addition, El-Awaisi quotes a Jewish historian stating that the Jewish response to the first Muslim conquest was positive, in that it brought an end to Byzantine rule. ${ }^{46}$

'Athāminah asserts that on the eve of the Muslim conquest the Jews were among a large minority who hated and resented Byzantine rule. ${ }^{47} \mathrm{He}$ adds that the Byzantine Empire had placed the Jews at the top of its list of enemies. ${ }^{48}$ It seems that at the time of the conquest of Jerusalem the Jews were no threat to the Christians as they were not living in the city, but were a minority scattered across al-Shām. El-Awaisi argues that the condition of excluding the Jews in al-Țabarī's version of the 'Assurance' is an infringement, addition or interpretation invented by some Muslim jurist, and he suggests it was produced as "part of the general conditions and the socio-political web that emerged there, which affected the position of the People of the Book and their treatment within the Abbasid State". ${ }^{49}$

It is possible that some time later, when the Christians accepted the reality of Muslim rule in Jerusalem and that Jews were no longer prevented from living in 
the region, the Christians felt threatened by this situation and inserted this condition into the Assurance recorded in al-Ṭabarī's version.

\section{The Expulsion of the Byzantines}

Al-Ṭabarī's version also stated that the Christians of Jerusalem must expel the Byzantines and thieves from living with them. It was quite natural that 'Umar should think of expelling them from Jerusalem. However, there was an apparent problem in the condition that allowed the Byzantines the option of staying in Jerusalem and paying jizyah, or leaving the city altogether. El-Awaisi maintains that 'Umar put Byzantines and robbers in the same category because both were, indeed, thieves. He argues that the Byzantines had occupied and stolen the land and its resources, while robbers had stolen the people's possessions. ${ }^{50}$ However, this condition appears to contain a contradiction. The beginning of the sentence says that the Byzantines must be expelled, while towards the end they are given the choice of leaving, or of staying and paying the jizyah. El-Awaisi suggests that a deeper understanding of this sentence reveals no contradiction, as it distinguishes between two groups of Byzantines. The first reference is to the Byzantine armed forces and robbers who must be expelled, and the second reference is to Byzantine visitors to the holy places. ${ }^{51}$

Al-'Affānī argues similarly that the text, or this condition, might have been inserted to distinguish between two groups. First, the Byzantine armies or soldiers, who should leave; second, those who visited the city as pilgrims or stayed for worship around the Christian holy sites. ${ }^{52}$

\section{The Question of Fulān}

The inhabitants of Jerusalem were given the opportunity to stay if they paid jizyah, or leave with the Byzantines and thieves. However, the statement also specifies "whosoever was in Aelia from the people of the land (ahlal-ard) before the murder of Fulān". ${ }^{33}$ Al-Quḍahh points out that this unknown name, Fulān, is mentioned in the document without the date of his murder. This makes it difficult to identify the person, so that it is impossible to implement the condition and to regard this as the text of a binding treaty. ${ }^{54}$ El-Awaisi argues that the phrase, "before the murder of Fulān," may refer to a person who was well-known at the time of the Muslim conquest. He suggests that the name might have been mis-transcribed from al-Ṭabarī's original manuscript, and could be 'falak', 'falaj', 'falāh' or 'fulān'. ${ }^{55}$

I agree that Fulān may refer to a well-known person, but not with El-Awaisi's interpretation. A search of narrations about the circumstances surrounding the conquest of Aelia reveals that the name Fulān ${ }^{56}$ appears in more than one of them. For example, al-Tabarī, when dealing with the Arab victory over the Byzantines 
at the battle of Ajnadīn (634), records that when 'Amr b. al-'Āṣ was fighting the Byzantine commander "Artabān" in Palestine, 'Amr was joined by 'Alqamah b. Hakīm and Masrūq b. Fulān al- 'Akkī in his battle with the Christians of Jerusalem. ${ }^{57}$ From this, it seems that a 'Fulān' was known as the father of one of the Muslim leaders. If this is correct, then he was neither an inhabitant of Jerusalem, nor a Byzantine, nor a thief. ${ }^{58}$

Al-Ṭabarî's version of 'Umar's 'Assurance', recorded nearly 300 years later, invites some further observations. The first is about the date of $15 \mathrm{AH}(636 \mathrm{CE})$ at the end of the document. There is no doubt that this was not in the original, but was added later. If it was correct, it would have led to differing opinions about the date of the conquest of Jerusalem, ${ }^{59}$ which was not the case - the consensus is that it was $16 \mathrm{AH}$.

Further, it was not until the sixteenth year after the hijrah that 'Umar inaugurated the hijri calendar, ${ }^{60}$ and it is very doubtful that al-Tabarî's document would share the same date as the hijrī, especially since Sayf refers to a false date used by al-Tabarī. Besides, al-Balādhurī reports that 'Amr b. al- 'Āṣ began the siege of Jerusalem after the victory of al-Yarmūk in $15 \mathrm{AH}$ and that $\mathrm{Abu}$ ' Ubaydah came to help him in $16 \mathrm{AH}$. It is therefore inconceivable that any document before the sixteenth year of the hijrah could be dated using the hijri calendar. ${ }^{61}$ This means that the date in al-Tabarī's version was added later.

Another issue concerns the witnesses used in this document. It is very surprising that Abū 'Ubaydah is not one of them, as he was chief commander of the Muslim armies. Abū 'Ubaydah might also have been expected to be a witness: it was he who asked 'Umar to come to the city to complete its surrender, and who communicated between 'Umar and the Christians of Aelia.

To sum up, the essential authenticity of 'Umar's 'Assurance of Safety' is beyond doubt, and it should be accepted as historically factual. Its key statements are guarantees of security to the Christians of Jerusalem about their churches and goods, a commitment to exclude "Byzantines and thieves", and the imposition of the jizyah tax. However, the later date of its appearance, the evident elaborations in the text, the inaccuracy of its dates, and its confusion and repetitions do not allow me to state with certainty that al-Tabarī's text is the original unembellished text of the 'Assurance' given by 'Umar to the Christians of Jerusalem. It has become evident that some clauses, in particular the exclusion of Jews from the city, were fabricated later and attributed to 'Umar.

\section{Conclusion}

There is no doubt that the attitude of the Prophet Muhammad and the Caliph 'Umar b. al-Khatțāa towards the two non-Muslims communities (in Medina and 
Jerusalem) did not arise out of a vacuum, but was inspired by religious injunctions and principles. This is clearly manifested in the two important documents that were issued firstly to the Jews of Medina by the Prophet himself and secondly, to the people of Jerusalem by 'Umar. The 'Constitution of Medina' and 'Umar's 'Assurance of Safety' stand as important examples for leaders in multi-faith societies today, and history has proven that when these examples were put into practice, non-Muslims were treated kindly and justly.

These examples of Muslim and non-Muslim coexistence are not confined to a specific time or place, but are meant to be applied in all times and places. Today, for example, Jordan's constitution guarantees freedom of religious belief. Christians in Jordan, who form the majority of non-Muslims, enjoy by law nearly 10 per cent of the seats in parliament and have similar quotas at every level of government and society. Their holy sites, property and religious practices are protected from any kind of interference by the state. We need to admit that cultural and social realities in many Muslim-majority societies have led to violations of the rights of non-Muslims in contemporary times. Looking at Islamic history, however, shows that the path towards mutual understanding and tolerance does not deviate from the essence of Islam. On the contrary, to revive the spirit of inclusivity, Muslim societies should look to the Qur'ān, and emulate the model it lays out. Finally, an inclusive vision is, and always will be, the only safe haven for followers of other religions in an Islamic society.

\section{Notes}

1. The Roman emperor Hadrian (Publius Aelius Hadrianus, r. 117-138) rebuilt the city as a Roman colony under the name of Colonia Aelia Capitolina in 135 after suppressing the Jewish revolt of Shimon bar Kokhba; see John Wilkinson, "Jerusalem under Rome and Byzantium: 63 BC-637 AD”, in: K.J. Asali (ed.), Jerusalem in History (New York: Olive Branch Press, 1990), 88.

2. 'Abd al-Malik Ibn Hishām, al-Sìrah al-nabawiyyah (Cairo: Dār al-Taqwā, 1999), 2:108-10.

3. Safi-ur-Rahman Al-Mubarakpuri, Ar-Raheeq Al-Makhtum (The Sealed Nectar): Biography of the Noble Prophet (Riyadh: Dar-us-Salam Publications, 1996), 197-8.

4. Muhammad Sa 'ịd Ramaḍān al-Būṭī, "Mu āmalāt al-dawlah al-islāmiyyah li-ghayr al-muslimīn: al-Quds namūdhajan", Journal of Islamic Jerusalem Studies 3, no.1 (1999), 4-5.

5. al-Būțī, "Mu' āmalāt", 5 .

6. Muhammad Hamidullah, Introduction to Islam (Cairo: El-Falah for Translation, Publication and Distribution, 1997), 289.

7. Abd al-Fattah El-Awaisi, Introducing Islamicjerusalem (Dundee: Al-Maktoum Institute Academic Press, 2007), 96.

8. Ibid., 96-7.

9. Ibid., 97.

10. Dhimmah literally means 'pledge and guarantee'; see Ibn Manzūur, Lisān al 'arab (Beirut: Dār Ihyāè al-Turāth al- 'Arabī, 1999), 5:59; see also al-Fayrūzābādī, al-Qāmūs al-Muhịt (Beirut: Dār Ihyāè' al-Turāth al-'Arabī, 1991), 4:162.

11. In his translation of Sahīh Muslim, Siddiqi defines jizyah as "a tax, a sort of compensation to the Muslim State on the part of the non-Muslims living under the protection of the Muslim State for 
not participating in military service and enjoying the pact of protection (dhimmah)"; see Muslim, Șah̄ịh Muslim, tr. A. Siddiqi (Delhi: Adam Publishers and Distributors, 1996), 3:163.

12. Abū 'Abd Allāh Muhammad b. 'Umar al-Wāqidī, Futūh al-Shām (Cairo: al-Maktabah al-Tawfìqiyyah, n.d.), 1:336.

13. Ibid., 1:336.

14. 'Greater Syria', today's Syria, Jordan, Israel/Palestine and Lebanon.

15. Abū 'l-'Abbās Aḥmad b. Yaḥyā al-Balādhurī, Futūḥ al-buldān (Beirut: Mu'assasat al-Ma ārif, 1987), 188-9.

16. Today's Golan Heights.

17. al-Balādhurī, Futūh, 189.

18. Ibid., 189.

19. Abū 'l-Ḥasan 'Alī al-Shaybānī Ibn al-Athīr, al-Kāmil fí 'l-ta'rīkh (Beirut: Manshūrāt Muhammad 'Alī Bayḍūn, Dār al-Kutub al- 'Ilmiyyah, 1998), 2:348.

20. Aḥmad al-Ya 'qūbī, Ta'rīkh al-Ya 'qūbī (Beirut: Manshūrāt Muhammad 'Alī Bayḍūn, Dār al-Kutub al-'Ilmiyyah, 1999), 2:101.

21. Sa 'īd Ibn al-Bațrīq [Eutychius], al-Ta' 'rīkh al-majmū ' 'alā 'l-tahqīq wa 'l-tașdīq (Beirut: n.p., 1905), $2: 16$.

22. Zakariyyā al-Quḍāh, "Mu 'āhadat fath Bayt al-Maqdis: al- uhdah al-'umariyyah", in: Muhammad al-Bakhīt and Iḥsān 'Abbās (eds), Bilād al-Shām fì șadr al-Islām (Amman: University of Jordan and University of Yarmuk, 1987), 274; see also El-Awaisi, Introducing Islamicjerusalem, 70.

23. Abū 'l-Faraj 'Abd al-Raḥmān b. 'Alī Ibn al-Jawzī, Faḍā'il al-Quds (Beirut: Dār al-Āfāq al-Jadīdah,1979), 123-4.

24. Abū Ja far Muḥammad b. Jarīr al-Ṭabarī, Ta'rīkh al-umam wa 'l-mulūk (Beirut: Manshurat Muhammad 'Ali Baydun. Dar al-Kutub al-'Ilmiyyah, 1997 ), 2:449; See also Abū 'l-Fidā' Ismā ‘̄l b. 'Alī, Ta'rīkh Abì 'l-Fidā' al-musammā al-Mukhtașar fì akhbār al-bashar (Beirut: Manshūrāt Muḥammad 'Alī Bayḍūn, Dār al-Kutub al-'Ilmiyyah, 1997), 1:200; Ibn al-Athīr, al-Kāmil, 2:500; Abū 'l-Fidā' Ismā' īl b. Ibn Kathīr, al-Bidāyah wa 'l-nihāyah (Beirut: Dār al-Fikr, 1978), 7:55; and El-Awaisi, Introducing Islamicjerusalem, 61.

25. El-Awaisi, Introducing Islamicjerusalem, 61.

26. al-Tabarī, Ta'rīkh, 2:449; English trans. from El-Awaisi, Introducing Islamicjerusalem, 62-3.

27. 'Alī 'Ajīn, "al-'Uhdah al- umariyyah (dirāsah naqdiyyah)", al-Hikmah 10 (1996), 71.

28. The 'Pact of 'Umar', or 'ahd 'Umar, is a key document outlining the obligations of non-Muslims living in the Muslim state and defining the relationship of dhimmīs with Muslims and with the state. This document appeared after Caliph 'Umar's reign and is not relevant to the first Muslim conquest. The humiliating conditions towards non-Muslims in this document are foreign to the mentality of 'Umar and inconsistent with the consideration and extreme care he showed to dhimmiss.

29. Khalīfah Ibn Khayyāṭ al- 'Ușfurī, Tar '̄̄kh Khalīfah Ibn Khayyāt. Riwāyat Baqū Ibn Khālid (Beirut: Dār al-Fikr, 1993), 265.

30. Ibid., 274.

31. El-Awaisi, Introducing Islamicjerusalem, 61.

32. For example, the peace treaty given to the people of Damascus by Khālid Ibn al-Walīid in the year $14 \mathrm{AH}$. See al-Balādhurī, Futū $h, 166$. Another example is the peace treaty given to the people of al-Jazīrah by 'Ayyād b. Ghanam in 17 AH. See Abū 'Ubayd al-Qāsim Ibn Sallām, Kitāb al-amwāl (Beirut: Dār al-Kutub al-'Ilmiyyah, 1986), 220.

33. El-Awaisi, Introducing Islamicjerusalem, 57-8.

34. al-Quḍāh, "Mu'āhadat", 2:276.

35. Abd al-Aziz Duri, "Jerusalem in the Early Islamic Period: 7th-11th Centuries AD", in: K. J. Asali (ed.), Jerusalem in History (New York: Olive Branch Press, 1990), 107.

36. Muhammad al-Ḥimyarī, Kitāb al-raw ḍ al-mi țār fì khayr al-aqțār (Beirut: Maktabat Lubnān, 1984), 69.

37. Ibn al-Jawzī, Fad̄à'il al-Quds, 123-4.

38. El-Awaisi, Introducing Islamicjerusalem, 98. 
39. Qur'ān (60:8-9): “Allah forbids you not, with regard to those who fight you not for (your) faith nor drive you out of your homes, from dealing kindly and justly with them: For Allah loveth those who are just. Allah only forbids you, with regard to those who fight you for (your) faith, and drive you out of your homes, and support (others) in driving you out, from turning to them (for friendship and protection). It is such as turn to them (in these circumstances) that do wrong."

40. Karen Armstrong, "Sacred Space: The Holiness of Islamic Jerusalem", Journal of Islamicjerusalem Studies 1, no.1 (1997), 14.

41. Wilkinson, "Jerusalem under Rome and Byzantium", 88; 'Ārif al- 'Ārif, al-Mufașsal fĩ ta'rīkh al-Quds (Jerusalem: Maṭba at al-Ma ārif, 1986), 68; 'Ażmī Muḥammad Abū 'Alyān, al-Quds bayn al-ihtilāl wa 'l-tahrīr: 'abr al- 'ușūr al-qadìmah wa 'l-wusțā wa 'l-hadīthah (3000 BC-1967 CE) (Amman: Mu'assasat Bākīr li '1-Dirāsat al-Thaqāfiyyah, 1993), 132-3.

42. al- 'Ārif, al-Mufașșal, 68; Abū 'Alyān, al-Quds, 132-3.

43. Abū 'Alyān, al-Quds, 136-7.

44. al-Ṭabarī, Ta' rìkh, 2:418.

45. Khalīl Sarkīs, Tarikh al-Quds al-ma 'rūf bi Ta'rīkh Ūrshalīm (Cairo: Maktabat al-Thaqāfah al-Dīniyyah, 2001), 101.

46. El-Awaisi, Introducing Islamicjerusalem, 71.

47. Khalīl 'Athāminah, Filasțīn fì khamsat qurūn min al-fath al-islāmi hattā al-ghazw al-faranjī (634-1099) [Palestine in five centuries from the Islamic conquest to the Frankish invasion (634-1099)] (Beirut: Mu'assasat al-Dirāsat al-Filasțīniyyah, 2000), 161.

48. Ibid., 161.

49. El-Awaisi, Introducing Islamicjerusalem, 83.

50. Ibid., 66 .

51. Ibid., 65-6.

52. Sayyid al-'Affānī, Tadhkīr al-nafs bi-hadīth al-Quds (wa qudsāh) (Cairo: Maktabat Mu'ādh Ibn Jabal, 2001), 1:197.

53. Fulān is used in Arabic to refer to a person without specifying the name.

54. al-Quḍāh, "Mu'āhadat", 276.

55. El-Awaisi, Introducing Islamicjerusalem, 67.

56. It should be noted that the expression "before the murder of Fulān" was absent from Mujīr al-Dīn al-Hanbalî's version of 'Umar's 'Assurance', which is very similar to al-Tabarī's version.

57. al-Ṭabarī, Ta'rīkh, 2:447.

58. El-Awaisi, Introducing Islamicjerusalem, 67.

59. Othman Al-Tel, The First Islamic Conquest of Aelia (Islamic Jerusalem). A Critical Analytical Study of the Early Islamic Historical Narratives and Sources (Dundee: Al-Maktoum Institute Academic Press, 2003), 109-20.

60. Ibn Kathīr, al-Bidāyah, 7:73-4.

61. al-Quḍāh, "Mu'āhadat", 2:276. 